\title{
Some Brief Notes on Kai Māori
}

Food is a signifier of identity and status (Hayden, 1998, 2009; Hayden \& Villeneuve, 2011; Neill et al., 2015). In traditional times, Māori consumed a range of hunted, gathered, and cultivated foods (Royal \& Kaka-Scott, 2013). As a result of this diet, noninfectious diseases were low among Māori due to foods with higher levels of protective chemicals and nutrients (Cambie \& Fergusson, 2003).

Pākehā settlers brought new foods such as wheat and potatoes (see McFarlane, 2007; Wharemate, 2015; Zhu \& He, 2020 concerning potatoes specifically), corn, cabbage, and other vegetables (Royal \& Kaka-Scott, 2013). Pākehā also introduced sheep, pigs, goats, and poultry (Royal \& Kaka-Scott, 2013). These new foods added variation to the Māori diet.

Colonisation and land loss has negatively impacted Māori food sovereignty (Shirley, 2013), and povertyrelated food insecurity damages Māori health (Beavis et al., 2018). In addition, due to the consumption of cheaper, processed foods, Māori 
experience inexplicably high levels of obesity and associated illnesses, such as type 2 diabetes (Glover et al., 2019; McKerchar et al., 2021).

Indeed, McKerchar et al. (2015) argue that food security is one of the most significant issues facing Māori concerning nutrition. They note that the impacts of colonisation and urbanisation have resulted in the loss of kai gathering sites. Revitalising the gathering and consumption of kai Māori, McKerchar et al. (2015) assert, may increase food security for Māori.

Nan-Rēpora Marion Brown-was born in 1940 into the Patuheuheu hapū of Waiōhau (Rangiwai, 2015, 2019, 2021d). She grew up around her marae (Rangiwai, 2021d, 2021e). She recalled that every home in Waiohau had gardens and fruit trees. Even in later life, when she lived in Murupara, she and her siblings and their children and grandchildren would return to whānau land at Waiōhau to plant and tend to extensive kai gardens. Although these practices are rare among Māori today, restoring these practices would certainly improve food security for Māori (Stein et al., 2018). Nan's diet consisted of hunted, gathered, and cultivated foods, supplemented with flour, sugar, sausages, and other Pākehā food products. Of course, as food availability evolved, so did Nan's taste for modern foods and takeaways.

This paper provides some brief notes on kai MāoriMāori food and makes some notes about the Māori 
foods that I ate with Nan. This paper will be written in an autoethnographic way, drawing on personal experience, literature, and reflections (Rangiwai, 2021c).

\section{Enamel mugs}

My maternal great-grandparents and grandparents had enamel mugs. Essential kit for New Zealand soldiers in the 1940s (see Appleton, 2015, p. ii), these mugs seem to have been in common use among Tūhoe (see Doherty, 2010, pp. 27-28). Enamelware was made by coating metal substrate with powdered glass and firing at an extremely intense heat; the heat melted the powder, which then cooled and formed a highly durable and resistant coating (Emalco, 2020). The mugs we used were white with blue rims. Unfortunately, some of the enamel had chipped off, leaving black pits on the surface of the mugs. The mugs were very similar to the one pictured below. 


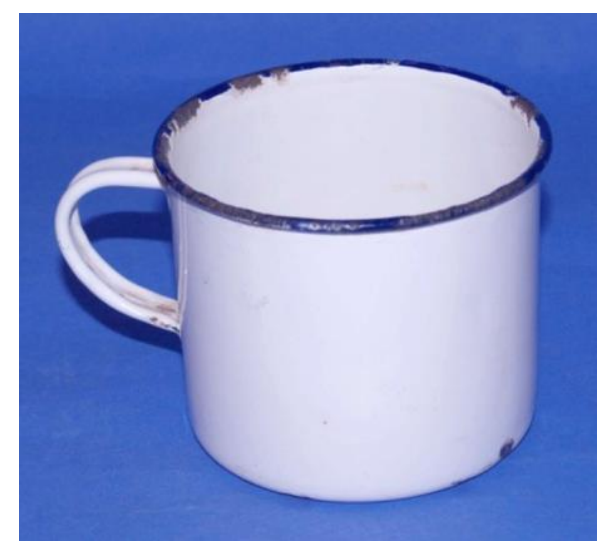

Figure 1. Enamel mug; belonged to 25577 Gunner EA (Ted) Frost, 7th Anti Tank Regiment, NZ Artillery, 2NZEF, WW2 (Auckland Museum, 2007).

These mugs were filled with tea which was consumed throughout the day. Nan would make for me tea with sugar and milk. I would dunk biscuits or cream crackers into the tea. I would sit and listen to the stories of my grandparents and greatgrandparents. I would listen to them talk and gossip, in te reo Māori, with their relatives and friends. Drinking tea and sitting at the table listening was how I gained and learned various bits of kōrero. Tea is now considered a very Māori drink.

\section{Hānḡi}

The hāngī is a traditional Māori way of cooking food, well-suited to cooking for large numbers; smaller portions of food were cooked using embers (Royal $\&$ 
Kaka-Scott, 2013). As with other people's of the Pacific, Māori cooked food in an umu or earth oven using the following process:

A pit is dug in the earth, in which a fire is burned for a number of hours to heat stones. Once these stones are hot, food in woven baskets is placed on top, covered in leaves [or wet sackcloth] and then soil. After the required cooking time, the soil and leaves are removed and the food is ready to be served (Rangiwai, 2015, p, 146).

For Patuheuheu the hāngì became symbolic of hope and restoration owing to Te Kooti Arikirangi Te Tūruki's prophecy concerning Te Umutaoroa-the slow-cooking earth oven. In 1886, due to severe land loss, Te Kooti offered to our hapū a prophecy of hope that promised the coming of a new leader who would unearth a hāngi $\overline{1}$ and restore all that was lost (Rangiwai, 2010a, 2010b, 2010c, 2011a, 2011b, 2011c, 2011d, 2011e, 2012a, 2012b, 2012c, 2012d, 2012e, 2012f, 2012g, 2012h, 2013a, 2013b. 2015, 2017a, 2017b, 2017c, 2017d, 2018a, 2018b, 2018c, 2018d, 2018e, 2018f, 2019a, 2019b, 2021a, 2021e). For this reason, the hāngi evokes mystical, religious, and even theological connotations among Patuheuheu. 


\section{Boil up and doughboys}

Pākehā introduced potatoes to Māori (Royal \& KakaScott, 2013). Potatoes were much easier for Māori to grow than kūmara, and pigs were easily reared (Royal \& Kaka-Scott, 2013). This resulted in the popularisation of the 'boil up' among Māori, which remains a favourite and staple dish (Royal \& KakaScott, 2013). Boil up is a dish of boiled pork/meat, potatoes, and vegetables such as pūhā or cabbage, sometimes served with other vegetables such as kamokamo, kumara, and pumpkin, along with steamed dumplings known as doughboys (Royal \& Kaka-Scott, 2013). Nan's boil ups were often accompanied by her handmade bread. Nan's 'go-to' weekly boil up was made with lamb or mutton neck chops.

\section{Bread}

Rēwena bread is Māori-style sourdough bread (Yazar \& Tavman, 2012). Sourdough is defined as a dough containing metabolically active microorganisms-lactic acid bacteria-that come from a sourdough mother sponge and that can be reactivated by adding flour and water (Catzeddu et al., 2006). Lactic acid bacteria are found in carbohydrate-rich environments, including plants, fermented foods, and the mucosal surfaces-those surfaces featuring mucosal fluid and which form part of the immune system (Wohlfert \& Russell, 2016)—of humans and animals (Florou-Paneri et 
al., 2012, n.p.). Among some of the first living organisms on earth, lactic acid bacteria have been around for three billion years (Pessione, 2012). Nan did comment that her rēwena 'bug' was very old!

Nan made the best rēwena bread. Ever. She cooked her bread in her special cast iron camp oven. She mixed the ingredients, kneaded the dough, and let it rise. Once baked, her rule was that the bread could not be cut until it had cooled down. Sometimes she broke this rule and allowed me to eat the bread hot, dripping with butter and jam, and washed down with hot, milky tea. The bread did not last long!

When Nan was growing up, she often cooked bread in a hole in the ground. A small hole was dug, a fire was lit in the hole, and the camp oven containing the prepared dough was placed inside the hole and covered with the embers. Royal and Kaka-Scott (2013) note too that this cooking method was used for cooking small quantities of food.

Nan also made another type of bread called pāpākiri (Rangiwai, 2019). Pāpākiri can mean scaly or flaky bark, as found on the rimu, mataī, monoao and kauri trees (Moorfield, 2011). However, in my whānau and hapū, Patuheuheu, we use the word to mean a type of round, flattened bread (Rangiwai, 2019). Pāpākiri is a Māori flatbread which is also known in other areas as takakau. Takakau is an unleavened bread (Moorfield, 2011) or simple damper (Royal \& Kaka-Scott, 2013). However, Nan 
used baking powder in her pāpāpkiri (which she also, jokingly, called "patero" bread!). Nan made the best pāpākiri, which we ate warm with lashings of butter (Rangiwai, 2019). Nan made pāpākiri often to accompany meals. Nan also made fried bread cooked in animal fat-beef dripping or lard rendered from wild pork.

\section{Kāuta}

In Māori homes, like the home that Nan grew up in, the kāuta, or kitchen, was located to the side of the house; it was not inside the house. Food was cooked over a fire in cast iron pots and pans. The crackling of the fire gave warmth, and through the heat of its flames, nourishment was provided to the whannau. As a source of energy, heat, and essentially, food, the fire of the kāuta was life-giving. In Māori life, the kāuta is both a site of abundance and scarcity, where food is cooked and distributed as required (Trego-Hall et al., 2019).

\section{Kererū}

For Tūhoe, kererū is a taonga: it is part of Tūhoe cultural identity, a highly prized food source, and is valued for its feathers (Feldman, 2001). Tūhoe possess traditional Indigenous knowledge about how to manage kererū populations (Lyver et al., 2008, 2009). In Tūhoe tradition, kererū is a special food reserved for women, particularly pregnant women and chiefs (Lyver et al., 2009). 
Nan ate the kererū first, and whatever was left was eaten by Papa. Nan fed me kererū flesh and waikōhua. It has a smell and taste that only those who have tasted it will recognise. The combination of the gamey flesh with the fragrance of the miro berries is distinct. While harvesting kererū is illegal, it is believed by some Tühoe that it is this very restriction that constrains the mauri of the kererusince the life-giving harvest rituals may not be performed as often or at all (Lyver et al., 2008).

\section{Mīi tahu}

Mìti tahu is meat that has been preserved by cooking meat and preserving it in its own fat (Collier, 2009; Doherty, 2010; Ryan, 2008). Mutton was a favourite source of meat to use for this preservation technique, mainly because the meat was very fatty. The meat could be stored for a long time in its own fat. When the meat was required, it could be reconstituted by placing it on top of pūhā simmering in a pot. Once reconstituted, the whānau could be fed. This is what Nan, and her generation grew up eating. It was one way that they preserved food for future use. It was a means of being prepared so that nourishment for the whānau and provisions for manaakitanga would always be available.

\section{Kānga wai}

Anyone who has had the (dis)pleasure of smelling kānga wai cooking in a pot knows that it has both a 
unique and pungent odour. Grown, prepared, and consumed by Māori since the 1800s, kānga wai is prized by some Māori for its distinctive flavour (Brooks et al., 2016). Brooks et al. (2016) opine that the characteristic flavour of kānga wai may be due to the production of $n$-butyric acid as a result of the 2-3-month fermentation process where maize is soaked in a stream or swamp. Indeed, the process of acid fermentation that kānga wai goes through may produce a product that is considered "safe" from a scientific standpoint (Whyte et al., 2001).

While the smell is, for many people, impossible to get past, once you do, you realise that the taste of kānga wai, or fermented corn, is exquisite and unique. Most often served with sugar and cream, kānga wai is a prized delicacy. Commonly known as rotten corn, the smell of kānga wai lives up to its English nickname. The smell of kānga wai and the pure pleasure of eating it reminds me of my greatgrandparents and grandparents. On one side of the family, the kānga was mashed with a texture like fine porridge, and on the other side of the family, it was left more or less as whole kernels swimming in a thick corn soup. 


\section{Pōkinikini' ${ }^{1}$}

Known by different names in different areas, such as repirepi/rerepi (P. Gloyne, personal communication, June 20, 2021), pōkinikini is a porridge-like dish made from flour and water. We also called it 'Māori porridge.'

To make pōkinikini, Nan made a dough with flour and water. Nan would pinch off pieces of dough into a pot of boiling water, which would cook in the water and gradually thicken the water to produce a porridge-like consistency. The pōkinikini was served with cream and sugar.

Very similar to pōkinikini, Tongans make tōpai and Samoans kopai-both are made or served with sugar and coconut cream (D. Enari, personal communication, June 20, 2021).

\section{Tuna}

When my grandmother was perhaps 14 or 15 , she wrote a letter to the editor of Te Ao Hou, which described some of the activities that our whānau engaged in based around gathering food and, in particular, tuna or eels. She mentions too that the eels were being gathered, and prepared by drying,

\footnotetext{
${ }^{1}$ I acknowledge te reo Māori expert, Paraone Gloyne, for assisting my thinking around the term pōkinikini. In a discussion with him, it was suggested that pō may come from the shortening of the word poi, which means to knead or make into balls (Moorfield, 2011). While the word kinikini, means to nip, pinch, or pinch off (Moorfield, 2011).
} 
for the Tekau-mā-rua, "the twelfth", which is a special time for the Ringatū faith held on the twelfth of the month.

Ki a Te Etita,

Tena koe. E tono atu ana ahau i taku reta ki a koe.

I te Rahoroi ra ka mea mai taku Papa ko wai e haere ki te toa ki te tiki pihuka mo a matau raina. Ka mea atu ahau ki taku Papa, ko 'hau. Ka haere ahau ma runga $i$ te pahi. Ka tae atu ahau ki te toa mea mai te Mangumangu, he aha taku pirangi. Ka mea atu ahau, he pihuka mo a matau raina. I taku taemaitanga ki te kainga ka haere matau ki runga o Waikokopu ki te hi tuna mo te tekau-ma-rua a te Hahi Ringatu. Ka uru atu matau ki roto o Waikokopu ka pahi matau i te awa tuatahi me te awa tuarua me to awa tuatoru. I to matau taetanga atu ki te waiariki ka mea mai taku Papa me noho mai ahau ki reira. Ka haere taku Papa raua ko Rihari ki te hi tuna. Ka noho mai ahau ki te waiariki ki te kaukau. Kotahi haora pea ahau i reira ka hoki mai taku Papa raua ko Rihari i te hi tuna. Ka mea atu ahau, "E hia a korua tuna me nga taraute?" Ka mea mai a Rihari, "Hai aha mau?" Ka mea atu ahau ki a Rihari, "Hai kai maku." I to matau putanga mai i roto o Waikokopu ka kautehia e 'hau e hia nga tuna. I mea atu ahau ki taku Papa, "E rua tekau ma rima a korua tuna." I to matau taetanga mai ki te kainga, ka whakairiirihia e taku Mama nga tuna kia marokeroke ai $\mathrm{i}$ te ra. I te marokeroketanga o nga tuna ka tipokapokahia e taku Mama nga piropiro. Koianei te mututanga o taku korero, 
Na to hoa,

Na Repora Maki,

Ko te Kura Maori o Waiohau (Te Ao Hou, 1955, p. 46-47). ${ }^{2}$

The tuna is a spiritual guardian for my whānau but also an important food source. Oral narratives concerning the mauri of the tuna in the Rangitāiki River identify a particular Patuheuheu family who carried the mauri of the tuna in their respective rohe. In the 1990s, I recall Mr Mangu Clarke telling our Rangitahi College class about how my whānau, the Maki Nātana whānau, held the mauri of the tuna. A Facebook post from 12 March 2020 on the Ko Rangitaiki toku Awa page states:

The tuna of the Rangitaiki have long been the lifeblood of the people of the awa - particularly for the people of Te Ika Whenua valley upstream from Waiohau.

Different varieties of eel once available in the rivers including:

Black eels, called Mataamoe, which lived in holes in the Okahu Stream;

${ }^{2}$ Although Nan was Ringatū and described Ringatū practices concerning food in her letter, she also told me about how she remember her staunch Roman Catholic grandmother fasting regularly and refraining from meat each Friday (Rangiwai, 2015, 2019, 2021b, 2021d). 
The silver-bellied eels of the Rangitaiki, which Patuheuheu called Paewai;

Blind eels, called Piharau, which lived in the tributaries that flowed through the pumice lands; And yellow-bellied eels, which lived in swamplands.

In different places, they tasted different; some were ordinary, some were special, but all were considered taonga. While the eel culture was common to all the people of Te Ika Whenua, certain individuals and families possessed special knowledge about eeling.

It was their responsibility to protect this knowledge and to pass it on to the next generation. $\boldsymbol{A}$ Patuheuheu whanau with special knowledge was said to carry the mauri of the eels. The people of Ngati Manawa, Ngati Whare, and Patuheuheu had their own maramataka or fishing calendar. The appropriate time for eeling was at hinapouri or when the moon was darkest (Ko Rangitaiki toku Awa, 2020, n.p., emphasis added). 
I responded to the above post in the following way:

\begin{abstract}
Byron Rangiwai The Patuheuheu family is the Maki Natana whanau. Our whanau is known for eeling. In the early 1990s it was common knowledge among Ngati Manawa kaumatua that the Maki Natana whanau were able to eel in certain areas where others were not. This particular korero was relayed to our high school class during "Maori week" at Rangitahi College in 1994 during our visit to "Aniwhenua" dam (Aniwaniwa). Those who are old enough to remember my great grand father, Hapurona Ted Maki Natana, will know this.
\end{abstract}

Figure 2. Facebook response (Ko Rangitaiki toku Awa

$$
\text { page, 2020, n.p.). }
$$

\title{
Hākari
}

Feasting has been a significant custom throughout human societies for millennia (Hayden, 2009; Hayden \& Villeneuve, 2011). Hayden and Villeneuve (2011) uphold that feasting is fundamental to the development of social identities and memories, the building of political power, gender identities, allocating and completing work, and the occurrence of prestige technologies-artefacts or objects that indicate "wealth, success, and power" (Hayden, 1998, p. 11). For Māori, the ritual feast of the hākari is intended to neutralise tapu following a pōwhiri, tangihanga, or any event where levels of tapu are elevated (Mead, 2016).

The blissful feeling of having a full puku following a hākari is something that most Māori would know and understand. At the end of significant events such as tangihanga and unveilings, the hâkari is a 
ritual feast that lifts the tapu of death and allows mourners to incorporate themselves back into the common world. At the conclusion of Nan's tangihanga in December 2017, the whānau pani, the immediate, grieving family, us, sat on the main table and were given the best food. After eating, I went into the wharepuni and slept until the next morning. After three or four days of 'running on empty', with very little sleep, and very little food, the hākari allowed me to have a large meal, to listen to the singing and laughter of whānau, and to finally collapse in a heap, on a mattress in the wharepuni. 


\section{References}

Appleton, I. C. (2015). 'As a matter of fact I've just about had enough': Battle weariness and the 2nd New Zealand division during the Italian campaign, 194345 [Master's thesis, Massey University]. https://mro.massey.ac.nz/handle/10179/9869 Auckland Museum. (2007). Mug.

https://www.aucklandmuseum.com/collection/obj ect/am_humanhistory-object-664268

Beavis, B. S., McKerchar, C., Maaka, J., \& Mainvil, L. A. (2018). Exploration of Māori household experiences of food insecurity. Nutrition \& Dietetics: Journal of Dietitians Australia, 76(3), 344-352. https://doi.org/10.1111/1747-0080.12477

Boutell, C., Scott-Giles, C. W., \& Brooke-Little, J. P. (1966). Heraldry. Frederick Warne \& Co. LTD.

Brooks, J. D., Lucke-Hutton, M., \& Roskruge, N. (2016). Kaanga wai: Development of a modern preservation process for a traditional Maori fermented food. In A. McElhatton \& M. M. El Idrissi (Eds.), Modernization of traditional food processes and products (pp. 103-114). Springer. https://doi.org/10.1007/978-1-4899-7671-0

Cambie, R. C., \& Ferguson, L. R. (2003). Potential functional foods in the traditional Maori diet. Mutation Research/Fundamental and Molecular Mechanisms of Mutagenesis, 523-524, 109-117. https://doi.org/10.1016/S0027-5107(02)00344-5 Catzeddu, P., Mura, E., Parente, E., Sanna, M., \& Farris, G. A. (2006). Molecular characterization of 
lactic acid bacteria from sourdough breads produced in Sardinia (Italy) and multivariate statistical analyses of results. Systematic and applied microbiology, 29(2), 138-144. https://doi.org/10.1016/i.syapm.2005.07.013

Collier, H. (2009). Matariki-a symbol of survival. Indigenous Voices, Indigenous Symbols: A Journal Published by WINHEC 2009. 11-18. http://citeseerx.ist.psu.edu/viewdoc/download?do $\mathrm{i}=10.1 .1 .667 .8500 \& \mathrm{rep}=\mathrm{rep} 1 \% \mathrm{type}=\mathrm{pdf}$

Doherty, W. (2010). Mātauranga Tūhoe: The centrality of mātauranga-a-iwi to Mãori education [Doctoral thesis, University of Auckland].

Emalco. (2020). How is enamelware made. https://emalco.com/knowledge-base/how-isenamelware-made $/$

Feldman, J. W. (2001). Treaty rights and pigeon poaching: Alienation of Māori access to kereru, 18641960. Waitangi Tribunal.

Florou-Paneri, P., Christaki, E. \& Bonos, E. (2012). Lactic acid bacteria as source of functional ingredients. IntechOpen. https://doi.org/10.5772/47766

Glover, M., Wong, S. F., Taylor, R. W., Derraik, J. G. B., Fa'alili-Fidow, J., Morton, S. M., \& Cutfield, W. S. (2019). The complexity of food provisioning decisions by Māori caregivers to ensure the happiness and health of their children. Nutrients, 11(5), 1-17. https://doi.org/10.3390/nu11050994 
Hayden, B., \& Villeneuve, S. (2011). A century of feasting studies. Annual Review of Anthropology, 40, 433-449.

Henry, A. (ca 1920s). First school house at Waiohau. Alexander Turnbull Library.

https://natlib.govt.nz/records/23248518

Hörandner, W \& Carr, A. W. (2005). Christogram. In A.

P. Kazhdan (Ed.), The Oxford dictionary of Byzantium (n.p.). Oxford University Press. https://www-oxfordreference-

com.ezproxy.waikato.ac.nz/view/10.1093/acref/97 80195046526.001.0001/acref-9780195046526-e1056

Ko Rangitaiki toku Awa. (2012, March 12). The tuna of the Rangitaiki have long been the lifeblood of the people of the awa [status update]. Facebook. https://www.facebook.com/korangitaiki/posts/11 4799023462214

Lindsay, N., Haami, D., Tassell-Matamua, N., Pomare, P., Valentine, H., Pahina, J., Ware, F., \& Pidduck, P. (2020). The spiritual experiences of contemporary Māori in Aotearoa New Zealand: A qualitative analysis. Journal of Spirituality in Mental Health, 121.

https://doi.org/10.1080/19349637.2020.1825152 Lyver, P. O’B., Jones, C. J., \& Doherty, J. (2009). Flavor or forethought: Tuhoe traditional management strategies for the conservation of kereru (Hemiphaga novaeseelandiae novaeseelandiae) in New Zealand. 
Ecology and Society, 14(1), 1-18. https://www.jstor.org/stable/26268038

Lyver, P. O’B., Taputu, T., Kutia, S. T., \& Tahi, B. (2008). Tūhoe Tuawhenua mātauranga of kererū (Hemiphaga novaeseelandiae novaeseelandiae) in $\mathrm{Te}$ Urewera. New Zealand Ecological Society, 32(1), 717. https://www.jstor.org/stable/24058096 Mead, H. (2016). Tikanga Mãori: Living by Māori Values. Huia.

Metro South Health. (2015). Food and cultural practices of the Māori community in Australia-A community resource.

https://metrosouth.health.qld.gov.au/sites/defaul t/files/content/heau-cultural-profile-maori.pdf

McCarthy, A. (2011). Scottishness and Irishness in New Zealand since 1840. Manchester University Press.

McFarlane, T. R. (2007). The contribution of taewa (Maori potato) production to Maori sustainable development [Unpublished master's thesis, Lincoln University].

McKerchar, C., Bowers, S., Heta, C., Signal, L., \& Matoe, L. (2015). Enhancing Māori food security using traditional kai. Global Health Promotion, 22(3), 15-24.

https://doi.org/10.1177/1757975914543573 McKerchar, C., Lacey, C., Abel, G., \& Signal, L. (2021). Ensuring the right to food for indigenous children: A case study of stakeholder perspectives on policy options to ensure the rights of tamariki Māori to healthy food. International Journal for Equity in 
Health,

https://doi.org/10.1186/s12939-021-01407-4

Moorfield, J. C. (2011). Te Aka Māori-English, EnglishMāori dictionary. Pearson.

Neill, L., Williamson, D., \& Berno, T. (2015). Manaakitanga and Māori food: Theoretical perspectives of advancement. Locale: The Australasian-Pacific Journal of Regional Food Studies, (5), 84-101.

Pessione, E. (2012). Lactic acid bacteria contribution to gut microbiota complexity: Lights and shadows. Frontiers in Cellular and Infection Microbiology. https://doi.org/10.3389/fcimb.2012.00086

Rangiwai, B. (2010a). The effects of racism on Māori land loss: Colonising discourses for Patuheuheu and Ngāti Haka [Unpublished master's thesis, Te Whare Wānanga o Awanuiārangi].

Rangiwai, B. (2010b, April). Race, difference and identity: The effects of nineteenth-century racial discourse on Māori land loss. Presentation at Te Whare Wānanga o Awanuiārangi, Whakatāne, New Zealand.

Rangiwai, B. (2010c, August). My research journey: The effects of racism on Māori land loss. Presentation at the Māori and Pasifika Postgraduate Students Wānanga Series, Ngā Wai o Horotiu Marae, Auckland University of Technology, Auckland, New Zealand.

Rangiwai, B. (2011a, October). From prophecy to praxis: A critical analysis of Patuheuheu land loss, 
prophecy and hapū praxis. Presentation at Ngā Wai o Horotiu Marae, Auckland University of Technology, Auckland, New Zealand.

Rangiwai, B. (2011b, November). From prophecy to praxis: A critical analysis of Patuheuheu land loss, prophecy and hapū praxis. Presentation at the Māori and Pasifika Postgraduate Students Symposium, Awataha Marae, Auckland, New Zealand.

Rangiwai, B. (2011c). 'Race' and the politics of land loss: Colonising discourses for

Patuheuheu and Ngāti Haka. Te Kaharoa: The eJournal of Indigenous Pacific Issues, 4 (1), 40-96. https://www.tekaharoa.com/index.php/tekaharoa /article/view/112

Rangiwai, B. (2011d). Te Umutaoroa, Patuheuheu and Ngāti Haka: Towards a prophetic model for unity and transformation. Te Kaharoa: The eJournal of Indigenous Pacific Issues, 4 (1), 1-32. https://www.tekaharoa.com/index.php/tekaharoa Larticle/view/110

Rangiwai, B. (2011e, July). Towards a model for research and community development. Presentation at University of the South Pacific, Rarotonga Campus, Rarotonga, Cook Islands.

Rangiwai, B. (2012a, November). Te Kooti Arikirangi Te Turuki and Te Umutaoroa: From prophecy to decolonisation and praxis. Paper presented to the Tapuika iwi community at the Māori and Pasifika Postgraduate Students Wānanga Series 
Symposium, 23-29 November, Moko Marae, Waitangi, Te Puke, New Zealand.

Rangiwai, B. (2012b, May). Nineteenth-century prophetic resistance: The case of Te Kooti and the 'Waiohau Fraud'. Paper presented at 'Assembly', St Paul Street Gallery, Auckland University of Technology, Auckland, New Zealand.

Rangiwai, B. (2012c). The potential of prophecy: Māori prophetism and community development. Te Kaharoa: The eJournal of Indigenous Pacific Issues, 1(1), Special Edition 1, 69-85. https://www.tekaharoa.com/index.php/tekaharoa /article/view/96

Rangiwai, B. (2012d, June). The potential of prophecy: Mãori prophetism and community development. Paper presented at the International Indigenous Development Research Conference, University of Auckland, Auckland, New Zealand.

Rangiwai, B. (2012e, May). Prophecy and praxis: Mãori prophetic movements and community development. Presentation at the Māori and Pasifika Postgraduate Students Wānanga Series, Ngā Wai o Horotiu Marae, Auckland University of Technology, Auckland, New Zealand.

Rangiwai, B. (2012f, June). Prophecy and praxis: Māori prophetic movements and community praxis. Paper presented at the Native American and Indigenous Studies Conference, Mohegan Indian Reservation, Uncasville, CT. 
Rangiwai, B. (2012g, October). Prophecy and praxis: The Te Umutaoroa (earth oven of long cooking) research model and community development. Paper presented at He Wānanga: Māori leadership in literacy and numeracy, Waiariki Institute of Technology, Rotorua, New Zealand.

Rangiwai, B. (2012h, April). The Te Umutaoroa (earth oven of long cooking) research model. Presentation at University of the South Pacific, Rarotonga Campus, Rarotonga, Cook Islands.

Rangiwai, B. (2013a, September). Ngā mauri e waru: The development of the Te Umutaoroa (slow cooking earth oven) research model. Presentation at University of the South Pacific, Rarotonga Campus, Rarotonga, Cook Islands.

Rangiwai, B. (2013b, November). From the Rangihau model to the Te Umutaoroa hapu development model. Paper presented to the Tapuika iwi community at the Māori and Pasifika Postgraduate Students Wānanga Series Symposium, November, Moko Marae, Waitangi, Te Puke, New Zealand.

Rangiwai, B. (2015). Ko au ko Te Umutaoroa, ko Te Umutaoroa ko au: Toward a Patuheuheu hapu development model [Unpublished doctoral thesis, Auckland University of Technology]. https://openrepository.aut.ac.nz/handle/10292/8 $\underline{851}$

Rangiwai, B. (2017a). The critical theory of Te Kooti Arikirangi Te Turuki. Te Kaharoa: The eJournal on Indigenous

Pacific Issues, 10(1), 194- 
240. https://www.tekaharoa.com/index.php/teka haroa/article/view/165

Rangiwai, B. (2017b). Māori prophetic movements as sites of political resistance: A case study. Te Kaharoa: The eJournal on Indigenous Pacific Issues, 10(1), 130-

192. https://www.tekaharoa.com/index.php/teka haroa/article/view/160

Rangiwai, B. (2017c, November). Syncretism in Māori theology. Paper presented at MAI Doctoral Conference, November 16-18, Palmerston North.

Rangiwai, B. (2017d). Te Umutaoroa - the slowcooking earth oven: A case study of intergenerational transference. Te Kaharoa: The eJournal on Indigenous Pacific Issues, 10(1), 241275. https://www.tekaharoa.com/index.php/teka haroa/article/view/168

Rangiwai, B. (2018a). Ka mua, ka muri: A new transformative leadership theory based on a prophecy by Te Kooti Arikirangi Te Turuki. Te Kaharoa: The eJournal on Indigenous Pacific Issues, 11(1), 604-637.

https://www.tekaharoa.com/index.php/tekaharoa /article/view/239

Rangiwai, B. (2018b, July). Mãori prophetic leadership: Ka mua, ka muri - walking backwards into the future. Paper presented at Leadership Pacific Inaugural Conference, University of the South Pacific, Suva, Fiji. 
Rangiwai, B. (2018c, July). Mãori prophetic leadership: Ka mua, ka muri - walking backwards into the future. Paper presented at He Waka Hiringa: Master of Applied Indigenous Knowledge Session, Te Wānanga o Aotearoa, Māngere, Auckland.

Rangiwai, B. (2018d). Te Kooti's slow-cooking earth oven prophecy: A Patuheuheu account and a new transformative leadership theory. Te Kaharoa: The eJournal on Indigenous Pacific Issues, 11(1), 1-119. https://www.tekaharoa.com/index.php/tekaharoa /article/view $/ 240$

Rangiwai, B. (2018e). Te Umutaoroa: A model for Patuheuheu hapū development. Te Kaharoa: The eJournal on Indigenous Pacific Issues, 11(1), 21-100. https://www.tekaharoa.com/index.php/tekaharoa /article/view/176

Rangiwai, B. (2018f). Te Umutaoroa: A Patuheuheu research model. Te Kaharoa: The eJournal on Indigenous Pacific Issues, 11(1), 1-20. https://www.tekaharoa.com/index.php/tekaharoa /article/view/169/153

Rangiwai, B. (2019a). A Kaupapa Mãori study of the positive impacts of syncretism on the development of Christian faith among Māori from my faith-world perspective [Unpublished doctoral thesis, University of

Otago]. https://ourarchive.otago.ac.nz/handle/10523/984 $\underline{7}$

Rangiwai, B. (2019b). My syncretistic faith-world perspective. Te Kaharoa: The eJournal on Indigenous 
Pacific Issues, 12(1), 1-92.

https://www.tekaharoa.com/index.php/tekaharoa /article/view/279

Rangiwai, B. (2021a). Back to the future: Using prophecy to support Māori student success in tertiary education. Te Kaharoa: The eJournal on Indigenous Pacific Issues, 17(1), 1-29. https://www.tekaharoa.com/index.php/tekaharoa Larticle/view/356

Rangiwai, B. (2021b). Edward Fitzgerald-pioneer, coach driver, shepherd, and rabitter: A very brief reflection. Te Kaharoa: The eJournal on Indigenous Pacific Issues, 17(1), 1-11. https://www.tekaharoa.com/index.php/tekaharoa /article/view/338

Rangiwai, B. (2021c). It's about me! My approach to autoethnography. Te Kaharoa: The eJournal on Indigenous Pacific Issues, 17(1), 1-15. https://www.tekaharoa.com/index.php/tekaharoa Larticle/view/355

Rangiwai, B. (2021d). Nan's stories. Te Kaharoa: The eJournal on Indigenous Pacific Issues, 17(1), 1-22. https://www.tekaharoa.com/index.php/tekaharoa /article/view/347

Rangiwai, B. (2021e). Tama-ki-Hikurangi: A whare built for Te Kooti. Te Kaharoa: The eJournal on Indigenous Pacific Issues, 17(1), 1-25. https://www.tekaharoa.com/index.php/tekaharoa Larticle/view/340 
Royal, C. \& Kaka-Scott, J. (2013). Māori foods-kai Māori. Te Ara: The Encyclopedia of New Zealand. https://teara.govt.nz/en/maori-foods-kai-maori Rush, E. C., Hsi, E., Ferguson, L. R., Williams, M. H., \& Simmons, D. (2010). Traditional foods reported by a Māori community in 2004. MAI Review, 2, 1-10.

Ryan, P. M. (2008). The Raupō dictionary of modern Māori. Raupō.

Shirley, L. (2013). Is Māori food sovereignty affected by adherence, or lack thereof, to Te Tiriti o Waitangi. Future of Food: Journal of Food, Agriculture and Society, 1(2), 57-63.

Stanford, J. N. (2008). Child dialect acquisition: New perspectives on parent/peer influence. Journal of Sociolinguistics, 12(5), 567-596. https://doi.org/10.1111/j.1467$\underline{9841.2008 .00383 . x}$

Stein, K., Mirosa, M., \& Carter, L. (2018). Māori women leading local sustainable food systems. AlterNative: An International Journal of Indigenous Peoples, 14(2), 147-155.

https://doi.org/10.1177/1177180117753168

Te Ao Hou (1955, December). Children write from Waiohau.

http://teaohou.natlib.govt.nz/journals/teaohou/is sue/Mao13TeA/c25.html

Trego-Hall, T. P., Te Awhitu, L., \& Mikahere-Hall, A. (2019). The politics of Toheroa soup: A pūkōrero about whānau and me. Ata: Journal of 
Psychotherapy Aotearoa New Zealand, 23(2), 113122. https://doi.org/10.9791/ajpanz.2019.10

Yazar, G. \& Tavman, S. (2012). Functional and technological aspects of sourdough fermentation with lactobacillus sanfranciscensis. Food Engineeing Reviews, $4(3)$, 171-190. https://doi.org/10.1007/s12393-012-9052-1 Wharemate, Z. R. (2015). Investigations into the nutritional and sensory potential of taewa (Māori potatoes) [Unpublished doctoral thesis, Massey University].

Whyte, R., Hudson, J.A., Hasell, S., Gray, M., \& O'Reilly, R. (2001). Traditional Maori food preparation methods and food safety. International Journal of Food Biology, 69(3), 183-190. https://doi.org/10.1016/S0168-1605(01)00547-5

Wohlfert, E. A. \& Russell, M. W. (2016). Mucosal surfaces: Immunological protection. Engineering Life Sciences, 1-12.

https://doi.org/10.1002/9780470015902.a00009 42.pub2

Zhu, F., \& He, J. (2020). Physicochemical and functional properties of Maori potato flour. Food Bioscience, 33, 1-8. https://doi.org/10.1016/j.fbio.2019.100488 